Génét. Sél. Evol., 1984, 16 (4), 405-416

\title{
Linkage in cattle between the major histocompatibility complex (BoLA) and the $M$ blood group system
}

\author{
H. LEVEZIEL and H.C. HINES * \\ I.N.R.A., Laboratoire de Génétique biochimique, \\ Centre de Recherches zootechniques, F 78350 Jouy-en-Josas \\ * Immunogenetics Laboratory, Department of Dairy Science, \\ The Ohio State University, 2027 Coffey Road, Columbus, Ohio 43210, U.S.A.
}

\begin{abstract}
Summary
Relationships between the bovine Major Histocompatibility Complex (MHC) and 11 blood group systems were examined using genetic information obtained from 58 families with doubly-heterozygous parents. The data were analyzed by the lod-score method: Close to moderate linkage between the cattle MHC (BoLA complex) and 10 blood group loci, A, B, C, F, J, L, S, Z, R' and $T^{\prime}$ was excluded. Evidence for a close linkage between BoLA and the $M$ blood group system is presented and a recombination frequency of 0.04 was estimated. The possibility of a linkage disequilibrium in the BoLA-M system chromosomal region is suggested.
\end{abstract}

Key words : Cattle, histocompatibility, blood groups, linkage.

\author{
Résumé \\ Liaison génétique entre le Complexe Majeur d'Histocompatibilité (BoLA) \\ et le système $M$ de groupes sanguins des bovins
}

Les relations entre le Complexe Majeur d'Histocompatibilité (CMH) des bovins et les 11 systèmes de groupes sanguins ont été examinées en utilisant l'information génétique recueillie dans 58 familles de parents double-hétérozygotes. Les données ont été analysées par la méthode du lod-score. Toute liaison génétique étroite ou modérée entre le CMH bovin (complexe BoLA) et 10 des loci de groupes sanguins : A, B, C, F, J, L, S, Z, R' et $T^{\prime}$ est exclue. L'existence d'une liaison génétique étroite entre BoLA et le système $\mathbf{M}$ de groupes sanguins est établie, avec une fréquence de recombinaison estimée à 0,04 . La possibilité d'un déséquilibre de liaison au sein de la région chromosomique BoLA-système $M$ est suggérée.

Mots clés : Bovins, histocompatibilité, groupes sanguins, liaison génétique. 


\section{Introduction}

Following the demonstration of an essential biological role for the Major Histocompatibility Complex (MHC) in other species studied (reviewed in GoTZE, 1977), research on the cattle MHC has progressed enormously during the last few years. Previously, only the erythrocyte blood group systems were well known. Among the 11 systems identified, 2 complex systems had been considered as prime candidates for the hypothetical MHC of cattle : the B system because of its genetic diversity (OOSTERLEE \& Bouw, 1974 ; RUITERKAMP et al., 1977), and the S system because of its serological complexity (Grosclaude, 1965 ; Borovska \& Demant, 1967 ; IVANYI, 1973). Subsequent reports from several laboratories : Mc GARY \& STONE (1970), SCHMID \& CwIK (1972), OstranTRosenberg \& Stormont (1974), Bryan et al. (1975), and Folger \& Hines (1976) suggested that lymphocyte antigens were not under the control of these loci.

The existence of the cattle MHC (BoLA Complex) is now well established (reviewed by STONE, 1982). Studied independently by CALDWEll et al. (1977), AmORENA \& STONE (1978), and SPOONER et al. (1978), the BoLA Complex encodes for 17 class I antigens (see Proceedings, 1982) controlled by the BoLA-A locus (Oliver et al., 1981), class II antigens (HOANG-XUAN et al., 1982 ; NEWMANN et al., 1982), and contains a BoLA-D locus controlling the mixed lymphocyte reaction (USINGER et al., 1981).

In their first publication SPOONER et al. (1978) presented preliminary evidence that there did not appear to be any identity or close linkage between the BoLA locus and any blood group loci. They always observed the presence of the 4 possible genetic types in offspring of doubly-heterozygous bulls, but the data were in some cases limited. The data need to be expanded and the results confirmed. This paper presents analyses for genetic linkage between BoLA and eleven bovine blood group loci on data compiled from typing in France and in the United States.

\section{Materials and methods}

\section{A. Animals}

The animals used in these studies were from 13 different breeds: Normande, Française-Frisonne, Maine-Anjou, Holstein, Angus, Hereford, Limousin, Simmental, Chianina, Ayrshire, Guernsey, Jersey and Brangus. They were primarily from private farms in France as well as in the United States, with additional animals from experimental herds of the Département de Génétique animale (Institut National de la Recherche Agronomique, France), and from the university herds in the U.S.A. at The Ohio State University (Department of Dairy Science) and at the University of Wisconsin (Department of Agriculture). They consisted of dam-offspring pairs, generally half-sib families from artificial insemination sires, but in some cases in the U.S.A. were full-sib families obtained by embryo transfer. Some of the latter families were included in the Second North American Comparison Test, 1982. Correctness of parentage was verified by BoLA and blood group typing. Offspring with parentage incompatibilities were not included in the linkage evaluations. 


\section{B. BoLA typing}

The BoLA typing of these animals has been determined by the lymphocytotoxicity test, as previously described in detail in our publications : SPOONER et al. (1978), and NEWMAN \& HiNES (1979). The cytotoxic sera used in France were produced by skin grafts and purified by absorption (SPOONER et al., 1978) ; in Ohio, they were usually obtained by screening and selecting sera from foeto-maternal immunizations (HiNES \& NEWMAN, 1981), and in fewer cases were obtained by skin grafts or by immunization with lymphocytes followed by absorption. All of these sera were submitted to the last International BoLA Comparison Test in 1980 (see Proceedings, 1982).

\section{Blood Group Typing}

The blood group typing was performed by the Laboratoire des groupes sanguins des bovins, I.N.R.A., C.N.R.Z., Jouy-en-Josas, France, and by the Cattle Blood Typing Laboratory, The Ohio State University, Colombus, Ohio, U.S.A. The typing was done by standard hemolytic procedures, according to the techniques described in detail by GrosClaude et al. (1979), and HiNEs et al. (1977). The nomenclature used is that of the last international comparison test organized by the International Society for Animal Blood Group Research (I.S.A.B.R.) in 1981.

\section{Analysis}

The data analysis was performed by the lod-score : sequential probability method developed by MORTON (1955) for the detection of genetic linkage in familial data. The $Z$ value of -2 and +3 were considered respectively to exclude or to accept the existence of a linkage. In some cases, the $\chi^{2}$ to estimate the heterogeneity of the information between different families was calculated as indicated by CAVALLI-SFORZA \& BODMER (1971).

\section{Results}

The information collected in 58 families of doubly-heterozygous parents enabled us to determine the following genetic linkage relationships between the BoLA complex and the blood group loci :

1) Absence of close or moderate linkage between BoLA and 10 of the erythrocyte blood group systems

The calculated lod-score values ( $\mathrm{Z}$ values) shown in table 1 exclude close or moderate linkage between the bovine $\mathrm{MHC}$ and 10 of the blood group systems : the $\mathrm{Z}$ values are always less than -2 for recombination rates of 0.2 or lower; the values of $\Theta$ up to which linkage can be excluded for each system range from 0.21 (system L) to 0.37 (system $C$ ). Over these values, the lod-score are always negative up to $\Theta=0.50$ for systems $A, C, J, Z$ and $R^{\prime}$, whereas positive maximum values are obtained for systems $B, F, L, S$ and $T^{\prime}$. 


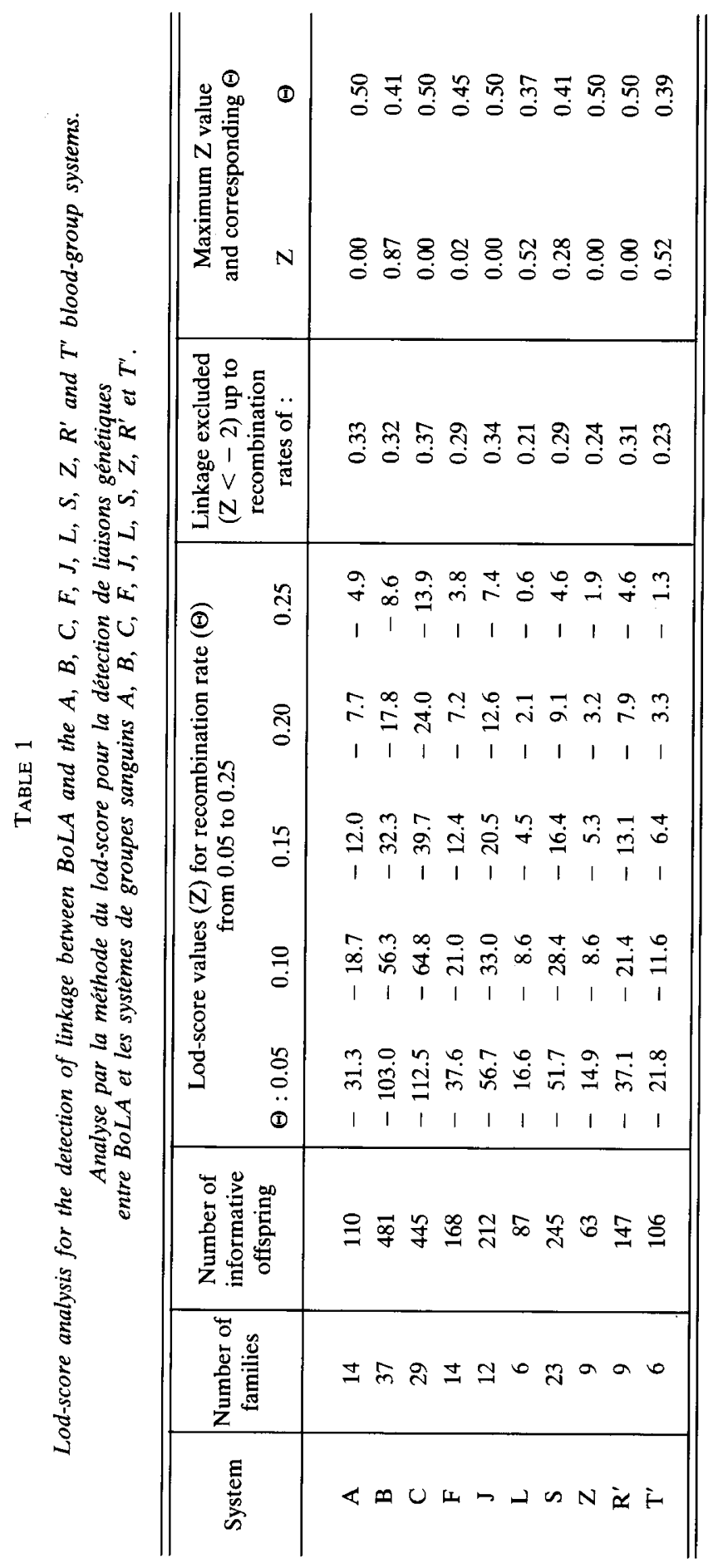




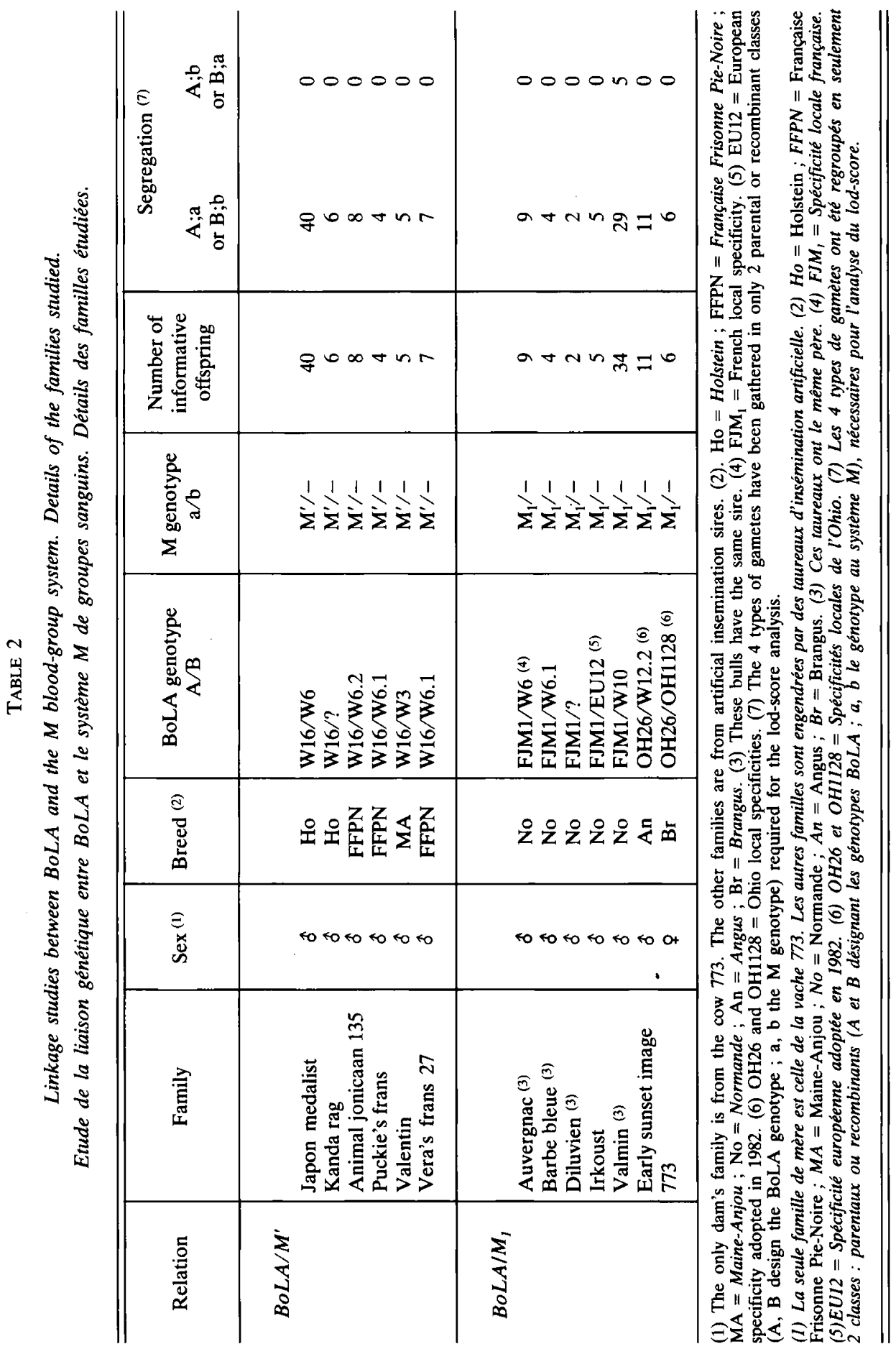


2) Genetic linkage between BoLA and the $M$ system

Table 2 lists all families relevant to analyses for linkage between BoLA and the $M$ system : the details pertaining to the BoLA genotype, the $M$ genotype, the number of informative matings, and the segregation of the gametes within the offspring. The genes for $M^{\prime}$ and $M_{1}$ was inherited respectively from 6 sires and from 6 sires and 1 cow. Only 5 putative recombinants occured within the family of the bull VALMIN.

Table 3 gives the lod-score values obtained for $M^{\prime}$ and for the $M_{1}$ factor, and shows clearly the existence of genetic linkage between the BoLA complex and each of the 2 factors. The $\mathrm{Z}$ values for the " $\mathrm{M}$ » system are obtained by addition of the values for $\mathbf{M}^{\prime}$ and $\mathbf{M}_{1}$, and we observe a lod-score value always greater than +3.0 . The estimation of the recombination rate between BoLA and the $M$ system is $\Theta=0.04$, giving a maximum value for $\mathrm{Z}$ of 29.13. Furthermore, in using as maximum value the limiting value for $Z$ when $\Theta=0.00$, the $\chi^{2}$ for heterogeneity does not indicate any divergence between the information collected in $\mathbf{M}^{\prime}$ segregating families and in $\mathbf{M}_{1}$ segregating families.

TABLE 3

Lod-score analysis; demonstration of the linkage between BoLA and the $M$ blood-group system.

Analyse par la méthode du lod-score; démonstration de la liaison génétique entre le complexe BoLA et le système $M$ de groupes sanguins.

\begin{tabular}{|c|c|c|c|c|c|c|c|c|c|c|}
\hline & \multirow{2}{*}{$\begin{array}{c}\text { Number } \\
\text { of } \\
\text { families }\end{array}$} & \multirow{2}{*}{$\begin{array}{c}\text { Number of } \\
\text { informative } \\
\text { offspring }\end{array}$} & \multicolumn{8}{|c|}{$\begin{array}{l}\text { Lod-score value }(\mathrm{Z}) \text { for recombination rates }(\Theta) \\
\text { from } 0.01 \text { to } 0.35\end{array}$} \\
\hline & & & 0.01 & 0.05 & 0.10 & 0.15 & 0.20 & 0.25 & 0.30 & 0.35 \\
\hline $\mathbf{M}^{\prime}$ & 6 & 70 & $* 18.96$ & 17.71 & 16.06 & 14.33 & 12.48 & 10.53 & 8.44 & 6.24 \\
\hline $\mathbf{M}_{1}$ & 7 & 71 & 8.98 & 11.30 & ${ }^{*} 11.25$ & 10.50 & 9.40 & 8.07 & 6.53 & 4.82 \\
\hline$« \mathrm{M} »^{\mathrm{a}}$ & 13 & 141 & 27.94 & $* * 29.01$ & 27.31 & 24.83 & 21.88 & 18.60 & 14.97 & 11.06 \\
\hline
\end{tabular}

$\mathrm{a}:$ : $\mathrm{M}$ » system : $\mathrm{ZM}=\mathrm{ZM}^{\prime}+\mathrm{ZM}_{1}$

The maxima are obtained for $\left\{\begin{aligned}{ }^{*} \mathrm{M}^{\prime}: \theta=0.00, \mathrm{Z}=19.27 \\ { }^{*} \mathrm{M}_{1}: \theta=0.07, \mathrm{Z}=11.41 \\ { }^{* *} \mathrm{M}^{*}: \theta=0.04, \mathrm{Z}=29.13\end{aligned}\right.$

$\chi^{2}$ for heterogeneity : $\chi^{2}(12)=7.11$ NS

$\chi^{2}$ d'hétérogénéité : $\chi_{(12)}^{2}=7.11 \mathrm{NS}$

The existence of a linkage disequilibrium within the BoLA region is also suggested by the observation that all $\mathrm{M}^{\prime}$ bulls involved in this linkage study share the W16 specificity and that they all transmit the combination $\mathbf{W} 16-\mathbf{M}^{\prime}$ in opposition to their other haplotypes (see tabl. 2). Similarly, all $\mathrm{M}_{1}$ bulls or cows have local BoLA specificities called FJM1 in France or $\mathrm{OH} 26$ in Ohio, and in each case the haplotypes FJM1-M ${ }_{1}$ or $\mathrm{OH} 26-\mathrm{M}_{1}$ are inherited by the offspring. 


\section{Discussion and conclusions}

The sequential probability test provides a powerful method of examining the possibility of chromosomal linkage between loci. The extensive diversity at the BoLA and several of the bovine blood group loci permitted the accumulation of large amounts of data for most paired-locus combinations. This allowed conclusions about linkage to be reached with considerable assurance. The extensive polymorphic variation also permitted the recognition of most instances of incorrectly recorded parentage.

Although fewer families were studied in France (20) than in the United States (38), the French data made a greater contribution to the linkage analysis. The situation can be explained by family structure differences between the 2 sets of data. In France the paternal half-sib families were fewer but larger, while in the United States although more families were examined, there were fewer offspring per family. In any case, a good agreement between the results was observed and we report only the cumulative values of the lod-score. For the $A, L, R^{\prime}$ and $T^{\prime}$ systems, conclusions could not have been reached without combining the data.

The first result we have established is the absence of close or moderate genetic linkage between BoLA and 10 of the blood group loci. This definitely eliminates any possibility of identity between BoLA and any of these systems; they must now be considered as strictly separate. That conclusion is of fundamental interest, especially for the complex systems B, C and S. The hypothesis of RuITERKAMP et al. (1977), who compared the bovine B system to the $\mathrm{H}-2$ complex in mice and suggested the B system could be the bovine MHC, is now formally dismissed. Furthermore, recent publications of Grosclaude et al. $(1979,1981)$ and GUERIN et al. (1981) which have contributed to the elaboration of linear genetic maps for the B and $\mathrm{C}$ systems have suggested that in addition to their genetic independance, these complex systems have a genetic structure distinguishable from the classical structure of the MHC (ANTCZAK, 1982). Similarly, the hypothesis that the S system could be the cattle MHC, suggested by the observation of serological complexity with the existence of non-linear subgroups, must now be disregarded. No firm conclusions can be drawn from our results regarding the possibility of loose linkage. However, positive maximum lod-scores were obtained for 5 blood group systems which, although not significant, could still represent loose linkage between any one of these systems and BoLA. Such linkage, if it exists, is unlikely to concern more than 2 of the 5 (one on either side of BoLA) since it is known that there is no close or moderate linkage between any of the 5 systems in question. Although further data are required to resolve the above point it is nevertheless clear that the BoLA complex constitutes a separate genetic system which is independent of the A, B, C, F, $J, L, S, Z, R^{\prime}$ and $T^{\prime}$ blood group systems.

A completely different situation occurs when the relationship between the $M$ system and the MHC is considered. M system factors, first reported in 1942 by FERGUSON et al. and elaborated upon in 1950 by STORMONT, appear to be under the control of an eleventh independent blood group system as was demonstrated by RENDEL (1958). Today, 2 antigenic factors, $\mathbf{M}_{1}$ and $\mathbf{M}^{\prime}$, are recognized but the gene frequencies of the encoding alleles are low, and the "null " allele has a frequency higher than 0.90 in almost all breeds tested. The control of these 2 factors by alleles of a single locus has been assumed on the basis of serological cross-reactivity of the antigenic determinants, but the critical family studies have not been reported. 
First suspected in only one bull family (a Normand bull : VALMIN) in which the $M_{1}$ factor was segregating (LEVEZIEL \& GUERIN, 1980) the linkage between BoLA and the $M$ system had to be confirmed in other families in which the segregation of the $\mathbf{M}^{\prime}$ factor could be analysed before it could be definitively established. Our results, utilizing families from different breeds for each of the factors $\mathbf{M}_{1}$ and $\mathbf{M}^{\prime}$, establish existence of a genetic linkage between the BoLA complex and the $\mathrm{M}$ blood group locus.

The calculated recombination rate of $\Theta=0.04$ between the BoLA and M loci must be regarded with some reservation and may be an overestimation ; all 5 putative « recombinants " occurred among the progeny of a single sire (VALMIN) but this family was tested between 1977 and 1979 and the recombinants were no longer available for retesting and absorption studies when the linkage between BoLA and M became apparent at a later date. However, the extensive blood group polymorphisms for which these animals were tested represent a powerful means of diagnosing incorrect parentage and this was not the case for any of the apparent recombinants. Furthermore the fact that so many recombinants were found in the same family, although unusual, should not necessarily be regarded with suspicion since it is known that, in stallions, there may be notable differences in recombination rates between sires (ANDERSSON \& SANDBERG, 1984). In any case, we are dealing with close linkage ; the confidence limits calculated using the Poisson distribution are $0.011<\Theta<0.083(\mathrm{P}=0.95$; symmetrical in probability).

The absence of heterogeneity between the familial data for $M_{1}$ and $M^{\prime}$ supports the belief that these 2 factors are controlled by the same locus, or by 2 closely linked loci since their segregation in combination with BoLA antigens does not differ significantly. However, only the segregation from parents with $\mathbf{M}^{\prime} / \mathrm{M}_{1}$ and correspondingly heterozygous BoLA genotypes will provide data pertinent to conclusive resolution of the question.

The existence of a linkage between the MHC and blood group loci has been described in other species; in that regard, the bovine species does not constitute a special case. A linkage has been reported in swine between the SLA complex and the $\mathrm{J}$ and $\mathrm{C}$ blood group loci (HRUBAN et al., 1976). Linkages between MHC and blood groups are known in rabbits (TISsOT \& COHEN, 1974) and in horses too (BAILEY et al., 1979). The B complex of chickens constitutes the only MHC which includes encoding for antigens specific for erythrocytes (PINK et al., 1977) and their progenitor cells (LONGENECKER \& MOSMANN, 1981). Other interesting situations arise in the mouse and human, where the blood groups $\mathrm{H} 2-\mathrm{G}$ and Chido/Rodgers, respectively associated with $\mathrm{H}-2$ and HLA complexes, appeared to be serologically detected products of within MHC complement genes (FERREIRA et al., 1980 ; O'NELl et al., 1978). Thus, it will be worth comparing the bovine situation to those different models in the future.

In addition to the genetic linkage we observed, we suggest the probable existence of a linkage disequilibrium in the BoLA region. This is an important characteristic of all other well-studied MHCs, and we report here the first such evidence in cattle. The local designations $\mathrm{FJM}_{1}$ or $\mathrm{OH} 26$ (which may possibly represent the same specificity) are not as well defined as W16; they behave as extra reactions recognized by our anti-W6 or anti-W16 sera in France or by anti-W6.2 sera in Ohio ; nevertheless, in our data all parents transmitted either the haplotype $\mathrm{W} 16-\mathrm{M}^{\prime}$ or the haplotypes $\mathrm{FJM}_{1}$ $\mathrm{M}_{1} / \mathrm{OH} 26-\mathrm{M}_{1}$ to their progeny. If this linkage disequilibrium could be confirmed at the population level and in several breeds (as seems to be the case in the French Pie-Noire and U.S. Holstein breed for $\mathrm{W} 16-\mathrm{M}^{\prime}$, and in the U.S. Angus breed for $\mathrm{OH} 26-\mathrm{M}_{1}$; unpublished), it would strengthen the analogy between BoLA and the other MHCs. 
In the light of our findings and the already described associations between HLA and diseases in man (DAUSSET, 1976), or between SLA and performance traits in swine (CAPY et al., 1981), earlier reports of the relationship of $\mathbf{M}$ blood group genes or associated BoLA haplotypes with physiological traits take on a new significance. The publication by MITSCHERLICH et al. (1959) of negative association between the M blood group antigen and milk production, the communication by Solbu et al. (1982) concerning a possible association between the W16 haplotype and an increased susceptibility to mastitis and the recently evidenced association of the $M$ blood group factor with susceptibility to mastitis (LARSEN et al., 1983), have to be considered with the greatest attention, taking in account our fundamental observations. Thus in addition to a better description of the BoLA region, the linkage we have established and the linkage disequilibrium we suggest lend support to the previously reported genetic marker associations. Additional investigations of relationships between the complex and measures of physiological performance appear to hold promise.

Received December 23, 1983. Accepted February 21, 1984.

\section{Acknowledgements}

The authors would like to thank all those who participated both in France and in the United States, and made possible the accumulation of large amounts of data required for the genetic study.

\section{References}

Amorena B., Stone W.H., 1978. Serologically Defined (SD) locus in cattle. Science, 201, 159-160.

Andersson L., SANDberg K., 1984. Genetic linkage in the horse. II. Distribution of male recombination estimates and the influence of age, breed and sex on recombination frequency. Genetics, 106, 109-122.

ANTCZAK D.F., 1982. Structure and function of the major histocompatibility complex in domestic animals. J. Am. Vet. Med. Assoc., 181, 1030-1036.

Bailey E., Stormont C., Suzuki Y., Trommershausen-Smith A., 1979. Linkage of loci controlling alloantigens on red blood cells and lymphocytes in the horse. Science, 204, 1317-1319.

Borovska M., Demant P., 1967. Specificity of cytotoxic antibodies in typing sera against cattle blood group antigens. Folia Biol. Praha, 13, 473-475.

Bryan C., Caldwell J., Weseli D.F., 1975. Analysis of the cattle histocompatibility system. J. Anim. Sci., 41, 247.

Caldwell J., Bryan C.F., Cumberland P.A., Weseli D.F., 1977. Serologically detected lymphocytes antigens of Holstein cattle. Anim. Blood Grps. Biochem. Genet., 8, 197-207.

Capy P., Renard C., Sellier P., Vaiman M., 1981. Etude préliminaire des relations entre le complexe majeur d'histocompatibilité (SLA) et des caractères de production chez le porc. Ann. Génét. Sél. Anim., 13, 441-446.

CAVAlli-Sfoza L.L., Bodmer W.F., 1971. The Genetics of human populations. 965 pp., Freeman W.H. \& Co, San Francisco.

Dausset J., 1976. Le complexe HLA. Les associations entre HLA et maladies. Nouv. Presse Méd., 5, 1477-1482. 
Ferguson L.C., Stormont C., IRWIN M.R., 1942. On additional antigens in the erythrocytes of cattle. J. Immunol., 44, 147-164.

Ferreira A., David C.S., Nussenzweig V., 1980. The murine H-2.7 specificity is an antigenic determinant of C4d, a fragment of the fourth component of the Complement System. J. Exp. Med., 151, 1424-1435.

Folger R.L., Hines H.C., 1976. Bovine Lymphocyte antigens : Serological relationships with erythrocyte and spermatozoan antigens. Anim. Blood Grps. Biochem. Genet., 7, 137-145.

GoTzE D. (ed.), 1977. The major histocompatibily system in man and animals. 404 pp., Springer Verlag, Berlin.

Grosclaude F., 1965. Studies on the S blood group system in French cattle breeds. Proceedings of the 9th European Conference on Animal Blood Groups, Prague, 18-22 August 1964, Publishing House of the Czechoslovak Academy of Sciences, Prague, 79-85.

Grosclaude F., Guerin G., Houlier G., 1979. The genetic map of the B system of cattle blood groups as observed in French breeds. Anim. Blood Grps. Biochem. Genet., 10, 199-218.

Grosclaude F., Alaux M.T., Houlier G., Guerin G., 1981. The C system of cattle blood groups. 1. Additional factors in the system. Anim. Blood Grps. Biochem. Genet., 12, 7-14.

Guerin G., Grosclaude F., Houlier G., 1981. The C system of cattle blood groups. 2. Partial genetic map of the system. Anim. Blood Grps. Biochem. Genet., 12, 15-21.

Hines H.C., Haenlein G.F.W., Zikakis J.P., Dickey H.C., 1977. Blood antigen, serum protein, and milk protein gene frequencies and genetic interrelationships in Holstein cattle. J. Dairy Sci., 60, 1143-1151.

Hines H.C., Newman M.J., 1981. Production of foetally stimulated lymphocytotoxic antibodies by multiparous cows. Anim. Blood Grps. Biochem. Genet., 12, 201-206.

Hoang-Xuan M., Charron D., Zilber M.T., Levy D., 1982. Biochemical characterization of class II bovine major histocompatibility complex antigens using cross-species reactive antibodies. Immunogenetics, 15, 621-624.

Hruban V., Simon M., Hradecky J., Jilek F., 1976. Linkage of the pig main histocompatibility complex and the J blood group system. Tissue Antigens, 7, 267-271.

IVANYI P., 1973. The major histocompatibility antigens in various species. Curr. Top. Microbiol. Immunol., 53, 1-90.

Larsen B., Jensen N.E., Madsen P., Nielsen S.M., Klastrup O., Madsen P.S., 1983. Blood groups in relation to bovine mastitis. 34th Annual Meeting of the European Association for Animal Production, Madrid, 3-6 October 1983 (Summaries), I, 359.

LeVeziel H., Guerin G., 1980. An attempt to detect genetic linkage between the major bovine histocompatibility system and other genetic markers. 17th Conference on Animal Blood Groups and Biochemical Polymorphisms, Wageningen, 28 July - 1 August 1980, roneotyped abstracts, 138 pp., 44.

LONGENECKER B.M., MosmanN T.R., 1981. Structure and properties of the major histocompatibility complex of the chicken. Speculations on the advantages and evolution of polymorphism. Immunogenetics, 13, 1-23.

MCGaRY D.R., Stone W.H., 1970. Immunogenetics studies of cattle lymphocytes (abst.). Fed. Proc., 29, 508.

Mitscherlich V.E., Tolle E., Walter E., 1959. Untersuchungen über das Bestehen von Beziehungen zwischen Blutgruppenfaktoren und Milchleistung des Rindes. Z. Tierz. Züchtungbiol, 72, 289-301.

MorTon N.E., 1955. Sequential tests for the detection of linkage. Am. J. Hum. Genet., 7, 177-318.

NewMan M.J., HiNES H.C., 1979. Production of foetally stimulated lymphocytotoxic antibodies by primiparous cows. Anim. Blood Grps. Biochem. Genet., 10, 87-92.

Newman M.J., Adams T.E., Brandon M.R., 1982. Serological and genetic identification of a bovine B lymphocyte alloantigen system. Anim. Blood Grps. Biochem. Genet., 13, 123-139.

Oliver R.A., Mc Coubrey C.M., Millar P., Morgan A.L.G., Spooner R.L., 1981. A genetic study of bovine lymphocyte antigens (BoLA) and their frequency in several breeds. Immunogenetics, 13, 127-132.

O'Neill G.J., Yang S.Y., Tegoli J., Berger R., Dupont B., 1978. Chido and Rodgers blood groups are distinct antigenic components of human complement $\mathrm{C}_{4}$. Nature, 273, 668-670. 
Oosterlee C.O., Bouw J., 1974. Structure of " loci » in animals. "Loci " structure in animal blood groups. 1st World Congress on Genetics Applied to Livestock Production, Madrid, 7-11 October 1974, 1, 243-252, Editorial Garsi, Madrid.

Ostrand-Rosenberg S., Stormont C., 1974. Bovine leucocyte antigens. Anim. Blood Grps. Biochem. Genet., 5, 231-237.

Pink J.R.L., Miggiano V.C., Ziegler A., 1977. Antigens of the chicken major histocompatibility B complex. Folia Biol. Praha, 23, 404-405.

«Proceedings», 1982. Proceeding of the Second International Bovine Lymphocyte Antigen (BoLA) workshop, 1982. Anim. Blood Grps. Biochem. Genet., 13, 33-53.

Rendel J., 1958. Studies of cattle blood groups. I. Production of cattle isoimmune sera and the inheritance of 4 antigenic factors. Acta Agric. Scand., 8, 40-61.

Ruiterkamp W.A., SPECK C.M., Bouw J., 1977. Structure of the blood group system B in cattle. II. A comparison between the blood group system B in cattle and the histocompatibility system H-2 in mice. Anim. Blood Grps. Biochem. Genet. (Abstracts of papers read at the 15th European Conference on Animal Blood Groups and Biochemical Polymorphisms, Dublin, $11-17$ July 1976), 8 (suppl. 1), 9.

SCHMID D.O., CwIK S., 1972. On leucocyte serology in the pig and cattle. Anim. Blood Grps. Biochem. Genet. (Abstracts of papers read at the 13th European Conference on Animal Blood Groups and Biochemical Polymorphisms, Vienna, 26 June - I July 1972), 3 (suppl. 1), 11-12.

SOlbu H., SPOONER R.L., LIE O., 1982. A possible influence of the bovine major histocompatibility complex (BoLA) on mastitis. 2nd World Congress on Genetics Applied to Livestock Production, Madrid, 4-8 October 1982, 7, 368-371, Editorial Garsi, Madrid.

Spooner R.L., Leveziel H., Grosclaude F., Oliver R.A., Vaiman M., 1978. Evidence for a possible major histocompatibility complex (BLA) in cattle. J. Immunogenetics, 5, 335-346.

StONE W.H., 1982. The bovine lymphocyte antigen (BoLA) system. Adv. Exp. Med. Biol., 137, 433-450.

Stormont C., 1950. Additional gene-controlled antigenic factors in the bovine erythrocyte. Genetics, 35, 76-94.

Tissot R.G., COHEN C., 1974. Histocompatibility in the rabbit. Linkage between RL-A, MLC, and the He blood group loci. Transplantation, 18, 142-149.

Usinger W.R., Curie-Cohen M., Benforado K., Pringnitz D., Rowe R., Splitter G.A., STONE W.H., 1981. The bovine major histocompatibility complex (BoLA) : close linkage of the gene controlling serologically defined antigens and mixed lymphocyte reactivity. Immunogenetics, 14, 423-428. 